\title{
The bioactive peptide endothelin causes multiple biologic responses relevant to myocardial and vascular performance after cardiac surgery
}

\author{
Francis G. Spinale, MD, PhD
}

\section{See related articles on pages 1114 and 1120 .}

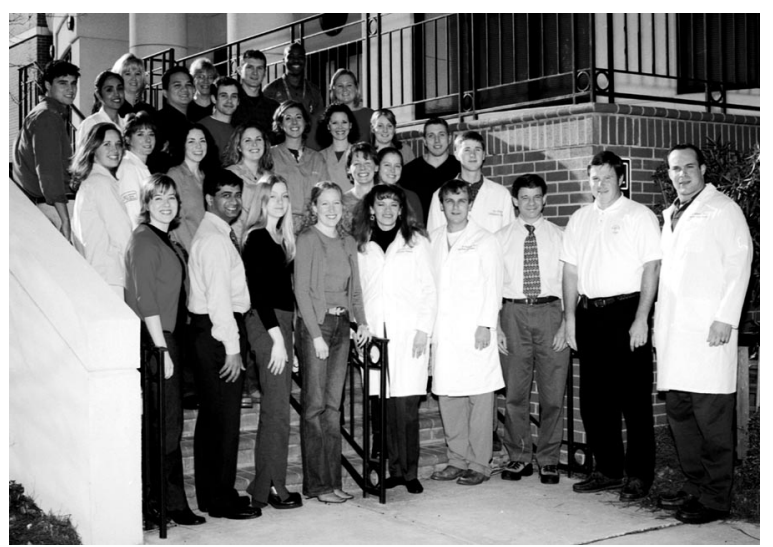

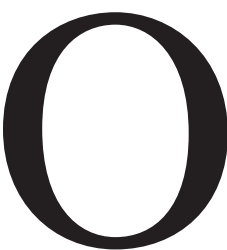

ver one-half million cardiac surgical procedures are performed in the United States and a large number of these procedures require cardiopulmonary bypass (CPB) and cardioplegic arrest. However, transient left ventricular (LV) dysfunction can occur with reperfusion and separation from $\mathrm{CPB}$ and result in a complex postoperative course. The causes for this LV pump dysfunction are multifactorial and include intrinsic defects in myocardial contractile performance and alterations in hemodynamic loading conditions. Neurohormonal system activation and subsequent release of bioactive peptides occur during and after CPB and cardioplegic arrest. One of the more potent bioactive peptides released into the systemic vasculature under these conditions is endothelin-1 (ET). ${ }^{1-9}$ Increased synthesis and release of ET has been implicated to exacerbate LV pump dysfunction in a number of cardiovascular diseases. ${ }^{8-12}$ Thus, elevated ET in patients during and after cardiac surgery may compromise LV function and contribute to a complex postoperative course. ${ }^{13-17}$ In the two companion studies by Verma and colleagues ${ }^{18,19}$ in this issue of the Journal, of Thoracic and Cardiovascular Surgery, the authors demonstrated that ET can contribute to myocardial cell injury and microvascular constriction after an episode of controlled ischemia-reperfusion, which was particularly pronounced in the context of hyperglycemia or diabetes. These findings add to the body of knowledge to suggest that ET contributes to abnormalities in cardiovascular regulation after cardioplegic arrest and $\mathrm{CPB}$ and can further exacerbate these processes in pre-existing disease states such as diabetes. Comprehensive reviews and texts on the molecular biology, biosynthesis, and signaling of ET have been published. ${ }^{7-10}$ However, a brief review with respect to the biology of ET and the different cellular functions within the cardiovascular system would be appropriate to place these recent studies into context with our emerging understanding of the importance of ET in the cardiac surgical setting.

From the Division of Cardiothoracic Surgery, Medical University of South Carolina, Charleston, SC.

Received for publication Dec 28, 2001; accepted for publication March 5, 2002.

Address for reprints: Francis G. Spinale, $\mathrm{MD}, \mathrm{PhD}$, Cardiothoracic Surgery, Strom Thurmond Research Building, 770 MUSC Complex, Suite 625, Medical University of South Carolina, Charleston, SC 29425.

J Thorac Cardiovasc Surg 2002;123:1031-4

Copyright (C) 2002 by The American Association for Thoracic Surgery

0022-5223/2002 $\$ 35.00+0 \quad \mathbf{1 2 / 1 / 1 2 4 6 6 8}$ doi: $10.1067 / \mathrm{mtc} .2002 .124668$

\section{ET and ET Receptor Systems}

The mature 21 amino acid peptide endothelin-1, or ET-1, is synthesized from a 38 amino acid precursor, also known as "big endothelin." Big ET is then converted to the biologically active ET-1 by an ET-converting enzyme. ${ }^{7}$ The diverse physiologic actions of ET-1 appear to be mediated through two receptor subtypes, the $\mathrm{ET}_{\mathrm{A}}$ and $\mathrm{ET}_{\mathrm{B}}$ receptors. However, the relative affinity of ET-1 for these receptor subtypes is equivalent. In light of the fact that ET-1 appears to be the most potent species of ET and has a high and equal affinity for both major receptor subtypes, then these peptide species are often referred to in generic terms as ET. The production of ET was first described in endothelial cells, but the synthesis of ET has now been identified to occur in a number of cell types including smooth muscle cells and cardiac myocytes. ${ }^{18,20-22}$ Thus, the production and release of ET can occur locally within the vascular and myocardial compartments, which in turn will regulate a number of physiologic processes. 


\section{ET and Vasoconstriction}

ET causes potent vasoconstriction of several vascular systems including the myocardial and pulmonary vascular systems. ${ }^{7-12}$ Potent constriction of vascular smooth muscle occurs primarily through binding of $\mathrm{ET}$ to the $\mathrm{ET}_{\mathrm{A}}$ receptor and, through several intracellular signaling events, increases calcium availability to the contractile elements. The $\mathrm{ET}_{\mathrm{B}}$ receptor contributes to the regulation of vascular smooth muscle tone in several different ways. First, $\mathrm{ET}_{\mathrm{B}}$ receptors located on endothelial cells mediate vasodilation via the release of nitric oxide and prostacyclins. ${ }^{7-9}$ Second, this receptor subtype can also exert vasoconstriction when located on the smooth muscle cells. ${ }^{10,12,23}$ Therefore, the net contractile effect of ET depends mainly on the relative density of $\mathrm{ET}_{\mathrm{A}}$ and $\mathrm{ET}_{\mathrm{B}}$ receptors on smooth muscle cells and of $\mathrm{ET}_{\mathrm{B}}$ receptors on endothelial cells. It has been reported previously that ET can induce a robust and prolonged vasoconstriction of internal thoracic artery and saphenous vein segments harvested for use as conduits in coronary revascularization procedures. ${ }^{5,24,25}$ Moreover, the vasoconstrictive effects of ET are more pronounced in arteries with atherosclerotic disease, and ET amplifies coronary artery contractions induced by norepinephrine and serotonin. ${ }^{24,25}$ Coronary atherosclerotic disease and heightened neurohormonal system activation coexist in the cardiac surgical setting and therefore may enhance the vasoconstrictive effects of ET within the myocardial vasculature. Past studies have demonstrated that alterations in ET sensitivity can occur within the systemic vasculature in diabetes. ${ }^{26,27}$ In the present report by Verma and colleagues, ${ }^{19}$ ET mediated a potent vasoconstrictive effect within the myocardial microvasculature, which was particularly pronounced in diabetic samples after CPB. These investigators reported diminished ET-mediated nitric oxide release in the diabetic myocardial samples. Thus, these new results coupled with past observations suggest that defects in the $\mathrm{ET}_{\mathrm{B}}$ receptor system occur in diabetes, which would result in an exaggerated vasoconstrictive response to ET.

\section{ET and Cardiac Myocyte Function}

Whereas the vasoconstrictive effects of ET are widely recognized, activation of the $\mathrm{ET}_{\mathrm{A}}$ receptor has direct effects on myocyte biology, including contractile protein interactions, inotropic state, protein expression, and electrophysiology. Studies from this laboratory and others have demonstrated abundant myocyte sarcolemmal ET receptors that are primarily of the $\mathrm{ET}_{\mathrm{A}}$ receptor subtype. ${ }^{21,22,28}$ Furthermore, these past studies demonstrated that the LV myocyte has the capacity to synthesize and release immunoreactive ET and activate local sarcolemmal $\mathrm{ET}_{\mathrm{A}}$ and $\mathrm{ET}_{\mathrm{B}}$ receptors. Thus, in addition to the systemic effects of ET, local myocyte ET production and $\mathrm{ET}_{\mathrm{A}}$ receptor activation may directly influence LV contractile processes. Recent studies have demonstrated that persistent activation of these ET receptor path- ways can directly result in a negative contractile effect in isolated LV myocytes, myocardial preparations, and in the intact LV. ${ }^{21,22,33-36}$

Fundamental intracellular events that have been reported to occur after $\mathrm{ET}_{\mathrm{A}}$ receptor activation are the release or release and mobilization of intracellular calcium $\left(\mathrm{Ca}^{+2}\right)$ and intracellular $\mathrm{pH}$ changes. ${ }^{28-32}$ Since $\mathrm{ET}_{\mathrm{A}}$ receptor activation can cause increased release of intracellular $\mathrm{Ca}^{+2}$, then activation of this receptor system after cardioplegic arrest and reperfusion would potentially exacerbate intracellular $\mathrm{Ca}^{+2}$ homeostasis and contractile function. An important sarcolemmal exchange system that directly influences intracellular $\mathrm{pH}$ is the $\mathrm{Na}^{+} / \mathrm{H}^{+}$exchanger. Intracellular $\mathrm{pH}$ under normal ambient conditions is maintained relatively alkaline when compared with the extracellular environment, and this is achieved through the transport of protons out of the myocyte. This exchange system has the capacity to correct an intracellular acid load during periods of ischemia through an acceleration of $\mathrm{H}^{+}$extrusion and intracellular accumulation of $\mathrm{Na}^{+}$. This increased intracellular $\mathrm{Na}^{+}$can, in turn, increase the exchange rate of the $\mathrm{Na}^{+} / \mathrm{Ca}^{+2}$ exchanger with a subsequent accumulation of intracellular $\mathrm{Ca}^{+2}$. Several studies have demonstrated that the $\mathrm{Na}^{+} / \mathrm{Ca}^{+2}$ exchanger directly contributes to the increased influx and accumulation of $\mathrm{Ca}^{+2}$ during ischemia and reperfusion. ${ }^{37,38}$ Thus, during early reperfusion, intracellular $\mathrm{Ca}^{+2}$ homeostasis could be further aggravated by the activation of the $\mathrm{Na}^{+} / \mathrm{H}^{+}$exchanger. ${ }^{39,40}$ It has been demonstrated that activation of the $\mathrm{ET}_{\mathrm{A}}$ receptor caused increased activity of the $\mathrm{Na}^{+} / \mathrm{H}^{+}$exchanger, intracellular alkalosis, and altered myocyte contractile performance. ${ }^{41,42}$ Thus, enhanced $\mathrm{ET}_{\mathrm{A}}$ receptor activation may further exacerbate the intracellular ionic homeostasis that can occur after cardioplegic arrest and reperfusion. In the companion study by Verma and colleagues, ${ }^{18}$ a human myocardial cell system was established and maintained under hyperglycemic conditions as well as after simulated ischemia-reperfusion. ${ }^{18}$ Several important findings regarding the ET system were identified from this study. First, a human myocardial cell culture system synthesized ET under basal conditions and was enhanced after ischemia-reperfusion. Second, the elaboration of ET with ischemia-reperfusion activated the $\mathrm{ET}_{\mathrm{A}}$ receptor and subsequently caused cell injury. Third, the $\mathrm{ET}_{\mathrm{A}}$ receptor-mediated cell injury was further pronounced in myocardial cell cultures maintained under hyperglycemic conditions. Thus, an acceleration of ET synthesis within the myocardial compartment with ischemia and reperfusion can cause detrimental effects on myocyte contractile performance and viability.

\section{Increased ET after Cardioplegic Arrest and CPB}

A 3- to 6-fold increase in systemic ET levels has been documented to occur immediately after cardioplegic arrest and reperfusion. ${ }^{1-6,19}$ A number of clinical studies have demonstrated that increased ET levels persist well into the 
postoperative period. ${ }^{1-5}$ The underlying mechanisms for the increased perioperative ET levels observed during and after cardiac surgery are probably multifactorial, including reduced ET clearance during CPB as a result of reduced pulmonary vascular flow, damage to endothelium as a result of absent pulsatile perfusion, increased myocardial ET production and release after reperfusion, increased stress from surgery, and enhanced ET biosynthesis due to thromboxane release from activated platelets. Animal studies have demonstrated a causative relationship between increased ET release and alterations in cardiovascular performance after cardioplegic arrest and CPB. ${ }^{14-17}$ Clinical studies have reported that elevated plasma ET levels in the early post-CPB period can be associated with a more complex postoperative course. ${ }^{4,5}$ However, ET is synthesized and released into the local interstitial space and, therefore, levels of this peptide that are detected in the systemic circulation likely reflect spill-over from local tissue compartments. ${ }^{6,18,20-22}$ With the use of microdialysis techniques, ET levels within the myocardial interstitium can be over 10-fold higher than systemic levels, and a rapid release of ET can occur within the myocardial compartment with cardioplegic arrest and reperfusion. ${ }^{6}$

The physiologic consequences of increased local myocardial ET production in the early post-cardiac surgical setting include vasoconstriction of the native coronary vasculature and newly placed coronary conduits that will hamper blood flow delivery to the vulnerable myocardium. In addition, increased ET exposure of myocytes immediately after cardioplegic arrest can exacerbate contractile function and inotropic responsiveness. ${ }^{14}$ Specifically, increased ET release and activation of myocyte ET receptors likely interfere in $\beta$-adrenergic-mediated inotropic response in this critical postoperative period. These past observations, as well as the reports by Verma and colleagues, ${ }^{18,19}$ suggest that ET may directly contribute to a number of pathophysiologic processes that can occur after cardioplegic arrest and CPB.

\section{ET Receptor Antagonists and Potential in Cardiac Surgery}

Potent and specific $\mathrm{ET}_{\mathrm{A}}$ receptor antagonists, as well as combined $\mathrm{ET}_{\mathrm{A}} / \mathrm{ET}_{\mathrm{B}}$ receptor antagonists, have been described. ${ }^{8-12}$ These new nonpeptide ET receptor antagonists are constructs with significant bioavailability, prolonged half-life, and high specificity. ET receptor antagonists have been successfully used in patients with pulmonary hypertension and heart failure. ${ }^{10-12}$ These ET receptor antagonists have been successfully used in several animal models of cardioplegic arrest and CPB. ${ }^{13,15-17}$ The ET receptor antagonist with the greatest clinical profile to date is the nonselective antagonist bosentan. ${ }^{12,43,44}$ Specifically, the immediate administration of bosentan in patients with heart failure has provided favorable effects on systemic hemodynamics and pulmonary hypertension. ${ }^{12,44}$

A clear change in the patient demographics for cardiac surgery such as coronary revascularization is ongoing, with the patients being older, having pre-existing abnormalities in LV structure and function, and having an increasing incidence of concomitant disease processes such as diabetes. The well-constructed series of in vitro studies performed by the Toronto cardiac surgery group demonstrated that the elaboration of ET after ischemia and reperfusion or after cardioplegic arrest can detrimentally affect a number of cardiovascular processes, particularly in the context of diabetes. ${ }^{18,19}$ Moreover, these investigators clearly demonstrated that ET receptor blockade could abrogate the deleterious effects of ET. An intravenous formulation of an ET antagonist has been developed and acute infusions of this mixed ET antagonist have been safely deployed in patients with severe heart failure. ${ }^{44}$ Although the effects of ET on myocardial function have received significant attention in heart failure, the potential deleterious effects of increased ET release and/or production within the myocardium after cardioplegic arrest and reperfusion and the underlying mechanisms for these effects are beginning to emerge. The time for well-designed, hypothesis-driven, preclinical and clinical studies regarding the mechanistic role of ET to contribute to postoperative recovery with respect to $\mathrm{LV}$ function, systemic hemodynamics, and coronary graft viability is now upon us.

\section{References}

1. Knothe CH, Boldt J, Zickmann B, Ballesteros M, Dapper F, Hempelmann G. Endothelin plasma levels in old and young patients during open heart surgery: correlations to cardiopulmonary and endocrinology parameters. J Cardiovasc Pharmacol. 1992;20:664-70.

2. Kirshbom PM, Page SO, Jacobs MT, Tsui SS, Bello E, Ungerleider RM, et al. Cardiopulmonary bypass and circulatory arrest increase endothelin-1 production and receptor expression in the lung. J Thorac Cardiovasc Surg. 1997;113:777-83.

3. Matheis G, Haak T, Beyersdorf F, Baretti R, Polywka C, Winkelmann BR. Circulating endothelin in patients undergoing coronary artery bypass grafting. Eur J Cardiothorac Surg. 1995;9:269-74.

4. Dorman BH, Bond BR, Clair MJ, Walker CA, Pinosky ML, Reeves $\mathrm{ST}$, et al. Temporal synthesis and release of endothelin within the systemic and myocardial circulation during and following cardiopulmonary bypass: Relation to postoperative recovery. $J$ Cardiovasc Anesth. 2000;14:540-5.

5. Bond BR, Dorman BH, Clair MJ, Walker CA, Pinosky ML, Reeves ST, et al. Endothelin-1 during and after cardiopulmonary bypass: association to graft sensitivity and postoperative recovery. $J$ Thorac Cardiovasc Surg. 2001;122:358-64.

6. Walker CA, Baicu SC, Goldberg AT, Widener CE, Fary DJ, Almany DK, et al. Temporal endothelin dynamics of the myocardial interstitium and systemic circulation in cardiopulmonary bypass. $J$ Thorac Cardiovasc Surg. 2000;120:864-71.

7. Webb DJ. Discovery of the endothelin family of peptides. In: Gray GA, Webb DJ, editors. Molecular biology and pharmacology of the endothelins. Austin: RG Landes; 1995. pp. 3-12.

8. Luscher TF, Barton M. Endothelins and endothelin receptor antagonists: therapeutic considerations for a novel class of cardiovascular drugs. Circulation. 2000;102:2434-40. 
9. Shiffrin EL, Intengan HD, Thibault G, Touyz RM. Clinical significance of endothelin in cardiovascular disease. Curr Opin Cardiol. 1997;12:354-67.

10. Miyauchi T. Pathophysiology of endothelin in the cardiovascular system. Ann Rev Physiol. 61999;1:391-415.

11. Williamson DJ, Wallman LL, Jones R, Keogh AM, Scroope F, Penny $\mathrm{R}$, et al. Hemodynamic effects of bosentan, an endothelin receptor antagonist, in patients with pulmonary hypertension. Circulation. 2000;25:411-8.

12. Roux S, Breu V, Ertel SI, Clozel M. Endothelin antagonism with bosentan: a review of potential applications. J Mol Med. 1999;77:36476.

13. Hiramatsu T, Forbess J, Miura T, Roth SJ, Cioffi MA, Mayer JE Jr. Effects of endothelin-1 and endothelin-A receptor antagonist on recovery after hypothermic cardioplegic ischemia in neonatal lamb hearts. Circulation. 1995;92(9 Suppl):II-400-4.

14. Dorman BH, New BR, Bond BR, Mukherjee R, Mukhin YV, McElmurray $\mathrm{JH}$, et al. Myocyte endothelin exposure during cardioplegic arrest exacerbates contractile dysfunction following reperfusion. Anesth Analg. 2000;90:1080-5.

15. Petrossian E, Parry AJ, Reddy VM, Akkersdijk GP, McMullan DM, Thompson L, et al. Endothelin receptor blockade prevents the rise in pulmonary vascular resistance after cardiopulmonary bypass in lambs with increased pulmonary blood flow. J Thorac Cardiovasc Surg. 1999:117:314-23

16. Pearl JM, Wellmann SA, McNamara JL, Lombardi JP, Wagner CJ, Raake JL, et al. Bosentan prevents hypoxia-reoxygenation-induced pulmonary hypertension and improves pulmonary function. Ann Thorac Surg. 1999;68:1717-21.

17. Joffs C, Walker CA, Hendrick JW, Fary DJ, Almany DK, Davis JN, et al. Endothelin receptor subtype A blockade selectively reduces pulmonary pressure after cardiopulmonary bypass. J Thorac Cardiovasc Surg. 2001;122:365-70.

18. Verma S, Maitland A, Weisel RD, Li SH, Fedak PWM, Pomroy NC, et al. Hyperglycemia exaggerates ischemia-reperfusion-induced cardiomyocyte injury: reversal with endothelin antagonism. $J$ Thorac Cardiovasc Surg. 2002;123:1120-4.

19. Verma S, Maitland A, Weisel RD, Fedak PWM, Li SH, Mickle DAG, et al. Increased endothelin-1 production in diabetic patients after cardioplegic arrest and reperfusion impairs coronary vascular reactivity: reversal by means of endothelin antagonism. J Thorac Cardiovasc Surg. 2002;123:1114-9.

20. Tonnessen T, Giaid A, Saleh D, Naess PA, Yanagisawa M, Christensen G. Increased in vivo expression and production of endothelin-1 by porcine cardiomyocytes subjected to ischemia. Circ Res. 1995;76: 767-72.

21. Ergul A, Walker CA, Goldberg A, Baicu SC, Hendrick JW, King MK, et al. Endothelin-1 in the myocardial interstitium in heart failure: relation to myocyte endothelin converting enzyme activity and expression. Am J Physiol. 2000;278:H2050-6.

22. Thomas PB, Liu ECK, Webb ML, Mukherjee R, Hebbar L, Spinale FG. Evidence of an endothelin-1 autocrine loop in cardiac myocytes: relation to contractile function with congestive heart failure. Am J Physiol. 1996;271:H2629-37.

23. Davenport AP, Maguire JJ. Is endothelin-induced vasconstriction mediated only by ETA receptors in humans? TIPS. 1994;15:9-11.

24. Davies MG, Klyachkin ML, Kim JH, Hagen P. Endothelin and vein bypass grafts in experimental atherosclerosis. $J$ Cardiovasc Pharmacol. 1993;22:S348-51.

25. Yang Z, Richard V, von Segesser L, Bauer E, Stulz P, Turina M, et al. Threshold concentrations of endothelin- 1 potentiate contractions to norepinephrine and serotonin in human arteries. A new mechanism of vasospasm? Circulation. 1990;82:188-95.
26. Mather K, Anderson TJ, Verma S. Insulin action in the vasculature: physiology and pathophysiology. J Vasc Res. 2001;38:415-22.

27. Hopfner RL, Gopalakrishnan V. Endothelin: emerging role in diabetic vascular complications. Diabetologia. 1999;42:1383-94.

28. Goldberg AT, Bond BR, Mukherjee R, New B, Zellner JL, Crawford FA, et al. The endothelin receptor pathway in human LV myocytes and relation to contractility. Ann Thorac Surg. 2000;69:711-5.

29. Ono K, Tsujimoto G, Sakamoto A, Eto K, Masaki T, Ozaki Y, et al. Endothelin A receptor mediates cardiac inhibition by regulating calcium and potassium currents. Nature. 1994;370:301-4.

30. Watanabe T, Kusumoto K, Kitayoshi T, Shimamoto N. Positive inotropic and vasoconstrictive effects of endothelin 1 in in-vivo and in-vitro experiments: characteristics and the role of the L-type $\mathrm{Ca}^{2+}$ channel. J Cardiovasc Pharmacol. 1989;13:S106-11.

31. Jones LG, Rozich JD, Tsutsui H, Cooper G. Endothelin stimulates multiple responses in isolated adult ventricular cardiac myocytes. Am J Physiol. 1992;263:H1447-54.

32. Kohmoto O, Ikenouchi H, Hirata Y, Momomura SI, Serizawa T, Barry WH. Variable effects of endothelin- 1 on $\left[\mathrm{Ca}^{2+}\right] \mathrm{I}$ transients, $\mathrm{pHi}$, and contraction in ventricular myocytes. Am J Physiol. 1993;265:H793800 .

33. Spinale FG, Walker JD, Mukherjee R, Iannini JP, Keever AT, Gallagher KP. Concomitant endothelin receptor subtype A blockade during the progression of congestive heart failure in rabbits has direct and beneficial effects on left ventricular and myocyte function. Circulation. 1997; 95:1918-29.

34. Onishi K, Ohno M, Little WC, Cheng CP. Endogenous endothelin-1 depresses left ventricular systolic and diastolic performance in congestive heart failure. J Pharmacol Exp Ther. 1999;288:1214-22.

35. Suzuki M, Ohte N, Wang ZM, Williams DJ, Little WC, Cheng CP. Altered inotropic response to endothelin-1 in cardiomyocytes from rats with isoproterenol-induced cardiomyopathy. Cardiovasc Res. 1998:39:589-99.

36. New RB, Sampson AC, King MK, Hendrick JW, Clair MJ, McElmurray J, et al. The effects of combined angiotensin II and endothelin receptor blockade with developing heart failure: effects on left ventricular performance, contractility and neurohormonal systems. Circulation. 2000;19:1447-53.

37. Sheu SS, Blaustein MP. Sodium/calcium exchange and control of cell calcium and contractility in cardiac and vascular smooth muscles. In: Fozzard HA, Haber E, Jennings RB, Katz AM, Morgan HE, editors. The heart and cardiovascular system. New York: Raven Press; 1992

38. Piper HM, Balser C, Ladilov YV, Schafer M, Siegmund B, Ruiz Meana $\mathrm{M}$, et al. The role of the $\mathrm{Na}^{+} / \mathrm{H}^{+}$exchange in ischemiareperfusion. Basic Res Cardiol. 1996;91:191-202.

39. Sholz W, Albus U. Potential of selective sodium-hydrogen exchange inhibitors in cardiovascular therapy. Cardiovasc Res. 1995;29:184-8.

40. Tani M, Neely JR. Role of intracellular $\mathrm{Na}^{+}$in $\mathrm{Ca}^{+2}$ overload and depressed recovery of ventricular function of reperfused ischemic rat hearts: possible involvement of $\mathrm{H}^{+}-\mathrm{Na}^{+}$and $\mathrm{Na}^{+} / \mathrm{Ca}^{+2}$ exchange. Circ Res. 1989;65:1045-56.

41. Ito N, Kagaya Y, Weinberg EO, Barry WH, Lorell BH. Endothelin and angiotensin II stimulation of the $\mathrm{Na}^{+} / \mathrm{H}^{+}$exchange is impaired in cardiac hypertrophy. J Clin Invest. 1997;99:125-35.

42. Khandoui N, Ho J, Karmazyn M. Role of $\mathrm{Na}(+)-\mathrm{H}+$ exchange in mediating effects of endothelin-1 on normal and ischemic/reperfused hearts. Circ Res. 1994;75:369-78.

43. Clozel M. Endothelin receptor antagonists: current status and perspectives. J Cardiovasc Pharmacol. 2000;35:S65-8.

44. Torre-Amione G, Young JB, Durand J, Bozkurt B, Mann DL, Kobrin I, et al. Hemodynamic effects of tezosentan, an intravenous dual endothelin receptor antagonist, in patients with class III to IV congestive heart failure. Circulation. 2001;20:973-80. 